\title{
A Brief Perspective on Lost Traditional Grains and Food Habits of Indians
}

\author{
Isha Sharma $^{1 *}$, Inderpreet Kaur Dhaliwal ${ }^{2}$, Priyanka Bijalwan ${ }^{3}$, \\ Vinod Kumar Yadav ${ }^{4}$ and Prashant Kaushik ${ }^{5}$ \\ ${ }^{1}$ Department of Commerce, Saurashtra University, Rajkot 360005, India \\ ${ }^{2}$ Punjab Agricultural University, Ludhiana 141004, India \\ ${ }^{3}$ Defence Institute of Bio-energy Research, DRDO, Pithoragarh, Uttarakhand-262501, India \\ ${ }^{4}$ Department of Botany, Ranchi University, Jharkhand, India \\ ${ }^{5}$ Nagano University, 1088 Komaki, Ueda, Nagano 386-0031, Japan \\ *Corresponding author
}

\begin{abstract}
A B S T R A C T
Keywords

Traditional, Indian, Food, Grain, Indian, Cultural

Article Info

Accepted:

16 November 2020

Available Online:

10 December 2020

To properly deal with a chronic illness, clinicians should provide their patients with practical resources to integrate into their daily lives. At the same time, an Asian Indian individual could be reluctant to follow a brand-new diet portrayed in a heart-healthy western cookbook but might be much more prepared to work within the classic preparation and recipes techniques of Indian culture. For sustainable lifestyle clinicians and individuals must work in concert to decide an appropriate. These techniques to include traditional, ancient grains right into a contemporary diet may also be extrapolated to many other highrisk populations which could take advantage of culturally sensitive medical advice on diet modification. Lastly, to enact efforts against the disease that is chronic over a significant scale, governments need to alter the methods their policies shape customer choices. Here, we put forth an attempt to spotlight the lost conventional food and grains practices of the India population since ages. We hope this information is going to help know the areas of Indian food tradition and the changes it has encountered during the $20^{\text {th }}$ century.
\end{abstract}

\section{Introduction}

A reputation of invasions, imperialism and migrations has shaped not just India's political and social position in the world, but also its food lifestyle across the subcontinent. ${ }^{1}$ Consequently, among the precedences for the Indian authorities was becoming selfsufficient to have the ability to nourish the nation's burgeoning population. Though the production of millets went terribly low, and the plants which were previously used in each home turned into a fodder harvest in only a couple of years after the green revolution. ${ }^{2,3}$

During various life stages, the body constitution changes, thereby demanding special eating habits to maintain regular physiological functions. ${ }^{4}$ Indian traditional food systems have the liable to cater to many natural body functions during various life phases and are thus capable of passing on nutrients through soluble parts into the human body. ${ }^{5}$ Conventional wisdom about food 
processing, its preservation and its therapeutic effects exists in India since time immemorial. Our ancestors used to have various meals which were healthy and nutritionally dense, although the styles of their preparation differ extending throughout an entire nation.

The conventional Indian foods have also been acknowledging as super foods due to the presence of body-healing chemicals, dietary fibres, antioxidants and probiotics in them. ${ }^{6,7}$ These functional molecules help in managing weight also as blood glucose levels and help to maintain immunity. $\mathbf{5}^{\mathbf{5}}$

The use of primitive grains, which do not have an associated negative perception, might offer a more straightforward method to integrate more healthful cereals into the contemporary Indian diet. ${ }^{8}$ Here we put forth an effort to highlight the lost traditional grains and food habits of the India population since ages. We hope this information will be useful in understanding the aspects of Indian food culture and the shift it has experienced during the last century.

\section{Importance of the right kind of food}

Food acts as a cultural construct concerning the meanings and emotions it evokes in people. Foods that are discerned as conventional have too little to be mutually exclusive to healthy foods. Similarly, foods that are conventional will not be equated with foods that are contemporary, sequentially boost poor cardiovascular health. Alternative contemporary mechanisms of preparations of traditional food ingredients can make them both nutritious and delicious simultaneously. The quantities of protein and dietary fiber in unprocessed grains are significantly more significant, coupled with meager proportions of carbohydrate to fiber and carbohydrate to protein ratios (Table 1).
Furthermore, while glycemic index of food items is the most commonly employ measure by nutritionists and clinicians working with diabetic individuals, depending on this measure alone for recommending diet changes is unadvisable. Other components of food, like protein and fat, significantly impact the glycemic index. Most contemporary dieticians agree that millets are a better replacement to wheat and rice, primarily because of their nutritional values and minimal glycemic indices which permit them to be significantly more appropriate for diabetics. Reintroduction of millets into the mainstream Indian diet began in organic stores and gourmet dishes but these have eventually begun appearing at the tiniest neighborhood provision stores as well. It is also reassuring to notice numerous mainstream South Indian vegetarian places providing millet variations of dosas, upmasandidlis. Ragi porridge is a good replacement for cereal or oats at breakfast. This millet is commonly accessible and is ideal for pongal or upmas. Many restaurants include millet dishes under their diet section.

Quality recipes for these grains turn up through Indian cookbooks and through oral tradition. For instance, chapatis and rotiscan be prepared with pearl millet and sorghum (jowar and bajra) flour rather than from refined wheat flour, along with adding healthy herbs into the dough. While these alternative cereals possess a distinct taste and texture than white rice and more nutritionally healthier and will considerably decrease the threat of Type II diabetes. Whole grains must be prepared with little amounts of saturated fat and salt for maximum health benefits. Sufficient attention must be given to teaching people on the suggested serving proportion of the different grains mentioned. People usually consume much more energy than they require, in significant part because of distorted perceptions of recommended serving proportions and sizes. 
Cereals like unpolished rice, barley, millet, and even sorghum will more than likely be for sale in Indian food stores. Other ancient grains not indigenous to the Indian subcontinent, like spelt, quinoa, or couscous, will probably just be discovered in mainstream and also gourmet food stores. While these complete, ancient grains might be somewhat costlier than purified grains, people who follow reduced carbohydrate diet plans won't need to buy the massive amounts of carbohydrates to which they are often used to. These suggestions must be created together with other daily recommendations, which includes reduction of fried festival foods and sweets; decrease of portion size, additional salt, and sugar in foods; and a focus on activity that is physical, such as both aerobic exercise and strength training.

The inclusion of traditional, ancient grains right into a contemporary diet may, in addition, be extrapolated to many other highrisk populations which could take advantage of culturally sensitive medical advice on diet modification. Lastly, to enact efforts against disease that is chronic over a significant scale, governments need to change the reasons their policies shape customer choices. Consequently, we, in addition, encourage national governments to contemplate reevaluating their subsidizations of crops which might have harmful effects on the wellness of the populations and environment.

\section{The traditional Indian diet}

By and large, a typical Indian diet is rich in carbohydrates (primarily refined cereals), low-quality proteins (primarily from legumes), rich gravies (high in saturated fats and salt) and has low levels of fresh fruits and vegetables. ${ }^{13}$ Before the nutrition transition in India because of the Green revolution of 1951, traditional meals and recipes were derived from whole-grain carbohydrates and included amaranth, barley, millet, and other ancient grains that have been grown on the Indian subcontinent for the past few millennia. ${ }^{14}$ Cereals have been the main staple of all Indian meals. ${ }^{15}$ They are nutritionally rich and provide energy to the body. This resulted in the modification in the usage design over the shift and the years in emphasis from the small cereals as well as pulses to the main cereals, wheat, and rice (Fig. 1). ${ }^{16}$

Overall, the decrease in the accessibility of pulses and millets per individual is primarily because of the more focus on the production of wheat and rice. ${ }^{17,18}$ According to Indian scriptures, viz., the Bhagavadgita, the Ramayana, the Manusmriti, every community had a separate and clear food belief system. Many of these, nonetheless, were impacted by the Aryan beliefs and practices, according to which, food was viewed as a gift from God that imparted strength. ${ }^{4}$

Aryans inhabited various parts of early India, and their first phase of settlement in India is referred to as the Vedic period. Their four Vedas, namely the Rigveda, the Samaveda, the Yajurveda and the Atharvaveda explain various cereal grains and their use in daily life. They understood about grain cultivation; parched grain was a typical strategy of processing employed by them. Lentils and rice were mixtures of complimentary food elements ingested. Barley evolved into their original staple food, while later texts note wheat, millets, lentils and sugarcane. The most used lentils were red, black and green lentils. Apupa was a kind of cake prepared by frying barley. Kichadi, made out of grain combined with lentils/dal, was extremely nourishing. The food items were categorized into three significant groups ${ }^{19}$ :

Satvika foods: These were consumed by the genuinely smart populace and included cooked veggies, fresh fruits, milk, and honey 
Tamasika foods: These drew out probably the lowest, crass characteristics of human behaviourand included red meat, garlic, liquor, and sour and spicy foods

Rajsika foods: These foods were consumed by labourers and provided plenty of power to handle everyday work.

Grains contribute $70-80 \%$ of daily calory intake in the Indian diet, which is much higher than normal. Replacing refined carbohydrates with healthier whole grains will subtly shift daily macronutrient composition slightly toward protein and away from carbohydrates. ${ }^{8}$ They have abundant quantities of iron, folic acid, vitamin $\mathrm{C}$, calcium, carotenoids (precursors of vitamin A) as well as phytochemicals. Some vegetables and meagre calories are given by fruits (Annexure 1). ${ }^{20}$ In comparison, several others, including potato, sweet potato, yam and tapioca and fresh fruits as banana are loaded with starch that provides electricity in the astounding amount. Therefore, fruits and vegetables may be utilized to improve or even decrease energy in the diet of ours.

\section{Benefits of whole grains}

The modern human diet is particularly high in refined carbohydrates and saturated fats but low in proteins, compared to other dietary traditions. ${ }^{14}$ Substitution of refined grains with ancient whole grains would be extremely beneficial since the overall amount of dietary carbohydrate would decrease, but the quality of carbohydrate would improve exponentially.

The benefits of whole grains have been widely evidenced through epidemiological studies in humans and animals; human response to glycemic effect and studies on lipids and adiponect in. In the chart below, you can see the difference in essential nutrients between whole wheat flour, refined wheat flour and enriched wheat flour (Fig. 2). Ancient whole grains provide less carbs and also much more proteins and also have advantageous micronutrients and fibres. ${ }^{21,22}$ Soluble fibres in whole grains contribute to reduced incidence of cardiovascular disease, and their effects can be enhanced by relatively slow digestion of whole-grain carbohydrates in the body; additionally, insoluble fibres in whole grains promote bowel health by speeding intestinal transit time with less reabsorption of water. ${ }^{22,23}$

A robust positive correlation has been depicted between refined grain intake and to a $20-30 \%$ reduction in Type II diabetes, thus confirming the defensive effect of fibre contained in whole grains. ${ }^{24-28}$ However, the perks of lower carbohydrate (35-40\%) and higher protein $(20-30 \%)$ diet include greater satiety, ${ }^{29,30}$ weight loss, ${ }^{31}$ and improved cholesterol and insulin parameters. ${ }^{20}$ Diabetic patients fed on wheat-and millet-based formulations exhibited lower glycemic indices than those fed on rice-based formulations. ${ }^{32}$ Millet protein fed to diabetic mice yielded several beneficial effects, viz., decreased glucose and triglyceride levels. ${ }^{33}$

Studies have postulated that boosting protein in the diet elevates satiety. ${ }^{29-30}$ Consumption of whole grains with reasonably high amounts of protein eventually results in lesser daily calorie intake.

When whole cereals are consumed in proper quantities and other healthy foods like vegetables and fruits are not displaced, they offer specific essential micronutrients, and their effects might be bolstered by the micronutrients provided in various other food items which are consumed at precisely the same time. ${ }^{2}$ 
Table.1 Proximate mean composition of cereals ${ }^{9-12}$

\begin{tabular}{|c|c|c|c|c|c|c|c|c|c|c|c|c|c|}
\hline Cereals & $\begin{array}{c}\text { Moist } \\
\text { ure } \\
(\%)\end{array}$ & $\begin{array}{c}\text { Crude } \\
\text { protein } \\
(\%)\end{array}$ & $\begin{array}{l}\text { Fat } \\
(\%)\end{array}$ & $\begin{array}{l}\text { Ash } \\
(\%)\end{array}$ & $\begin{array}{c}\text { Crude } \\
\text { fiber } \\
(\%)\end{array}$ & $\begin{array}{l}\text { Carbo } \\
\text { hydra } \\
\text { te }(\%)\end{array}$ & $\begin{array}{l}\text { Thia } \\
\text { mine } \\
\text { (mg) }\end{array}$ & $\begin{array}{c}\text { Ribofl } \\
\text { avin } \\
\text { (mg) }\end{array}$ & $\begin{array}{l}\text { Niacin } \\
(\mathbf{m g})\end{array}$ & $\underset{(\mathbf{m g})}{\mathbf{C a}}$ & $\underset{(\mathbf{m g})}{\mathbf{P}}$ & $\begin{array}{c}\mathrm{Fe} \\
(\mathbf{m g})\end{array}$ & $\underset{(\mathbf{m g})}{\mathbf{Z n}}$ \\
\hline Rough rice & 14.00 & 5.80 & $\begin{array}{l}1.50- \\
2.30\end{array}$ & $\begin{array}{l}2.90- \\
5.20\end{array}$ & $\begin{array}{l}7.20- \\
10.40\end{array}$ & $\begin{array}{l}64.00- \\
73.00\end{array}$ & $\begin{array}{l}0.26- \\
0.33\end{array}$ & $\begin{array}{l}0.06- \\
0.11\end{array}$ & $\begin{array}{l}2.90- \\
5.60\end{array}$ & $\begin{array}{l}10.00- \\
80.00\end{array}$ & $\begin{array}{c}170.00 \\
- \\
390.00\end{array}$ & $\begin{array}{l}1.40- \\
6.00\end{array}$ & $\begin{array}{l}1.70 \\
3.10\end{array}$ \\
\hline Brown rice & $\begin{array}{l}7.10- \\
11.60\end{array}$ & $\begin{array}{l}5.90- \\
11.00\end{array}$ & $\begin{array}{l}1.60- \\
2.80\end{array}$ & $\begin{array}{l}0.43- \\
2.34\end{array}$ & $\begin{array}{l}0.22- \\
0.95\end{array}$ & $\begin{array}{l}71.31- \\
84.75\end{array}$ & $\begin{array}{c}0.29- \\
0.61\end{array}$ & $\begin{array}{l}0.04- \\
0.14\end{array}$ & $\begin{array}{l}3.50- \\
5.30\end{array}$ & $\begin{array}{l}10.00- \\
50.00\end{array}$ & $\begin{array}{c}170.00 \\
- \\
430.00\end{array}$ & $\begin{array}{l}0.20- \\
5.20\end{array}$ & $\begin{array}{l}0.60 \\
2.80\end{array}$ \\
\hline Milled rice & 9.93 & 9.16 & 1.24 & 4.43 & 1.04 & 74.80 & $\begin{array}{l}0.02- \\
0.11\end{array}$ & $\begin{array}{l}0.02- \\
0.06\end{array}$ & $\begin{array}{l}1.30- \\
2.40\end{array}$ & $\begin{array}{l}10.0- \\
30.0\end{array}$ & $\begin{array}{l}80.00- \\
150.00\end{array}$ & $\begin{array}{l}0.20- \\
2.80\end{array}$ & $\begin{array}{l}0.60 \\
2.30\end{array}$ \\
\hline Red-colored rice & $\begin{array}{l}9.30- \\
13.10\end{array}$ & $\begin{array}{l}7.16- \\
10.85\end{array}$ & $\begin{array}{l}1.15- \\
3.19\end{array}$ & $\begin{array}{c}0.287- \\
0.61\end{array}$ & $\begin{array}{c}0.82- \\
1.5\end{array}$ & $\begin{array}{l}70.75- \\
81.29\end{array}$ & *NA & NA & NA & NA & NA & NA & NA \\
\hline $\begin{array}{l}\text { Chak-haoamubi (Manipur } \\
\text { black-colored rice) }\end{array}$ & 11.60 & 8.80 & 1.00 & 0.30 & 0.50 & 78.00 & NA & NA & NA & NA & NA & NA & NA \\
\hline Wheat & 12.00 & 11.60 & 2.00 & 1.60 & 2.00 & 71.00 & 0.41 & 0.10 & 5.10 & 30.00 & 315.00 & 3.50 & 2.85 \\
\hline Maize & 12.00 & 9.20 & 4.60 & 1.20 & 2.80 & 73.00 & 0.38 & 0.20 & 3.60 & 26.00 & 279.00 & 2.70 & 2.27 \\
\hline Sorghum & 12.00 & 10.40 & 3.10 & 1.60 & 2.00 & 70.70 & 0.38 & 0.15 & 4.30 & 25.00 & 274.00 & 5.40 & 1.96 \\
\hline Pearl millet & 12.00 & 11.80 & 4.80 & 2.20 & 2.30 & 67.00 & 0.38 & 0.21 & 2.80 & 42.00 & 289.00 & 11.00 & 2.76 \\
\hline Finger millet & 12.00 & 7.70 & 1.50 & 2.60 & 3.60 & 72.60 & 0.42 & 0.19 & 1.10 & 350.00 & 210.0 & 3.90 & 2.53 \\
\hline Foxtail millet & 12.00 & 11.20 & 4.00 & 3.30 & 6.70 & 63.20 & 0.59 & 0.11 & 3.20 & 31.00 & - & 2.80 & - \\
\hline Little millet & 12.00 & 9.70 & 5.20 & 5.40 & 7.60 & 60.90 & 0.30 & 0.09 & 3.20 & 17.00 & 130.00 & 9.30 & 1.82 \\
\hline Barnyard millet & 12.00 & 11.00 & 3.90 & 4.50 & 13.60 & 55.00 & 0.33 & 0.10 & 4.20 & 22.00 & - & 18.60 & - \\
\hline Kodo millet & 12.00 & 9.80 & 3.60 & 3.30 & 5.20 & 66.60 & 0.15 & 0.09 & 2.00 & 35.00 & 101.00 & 1.70 & 1.65 \\
\hline
\end{tabular}

Fig.1 Indicates an increase in the availability of rice and wheat per person and a decrease in the availability of pulses and millets per person after the Green Revolution

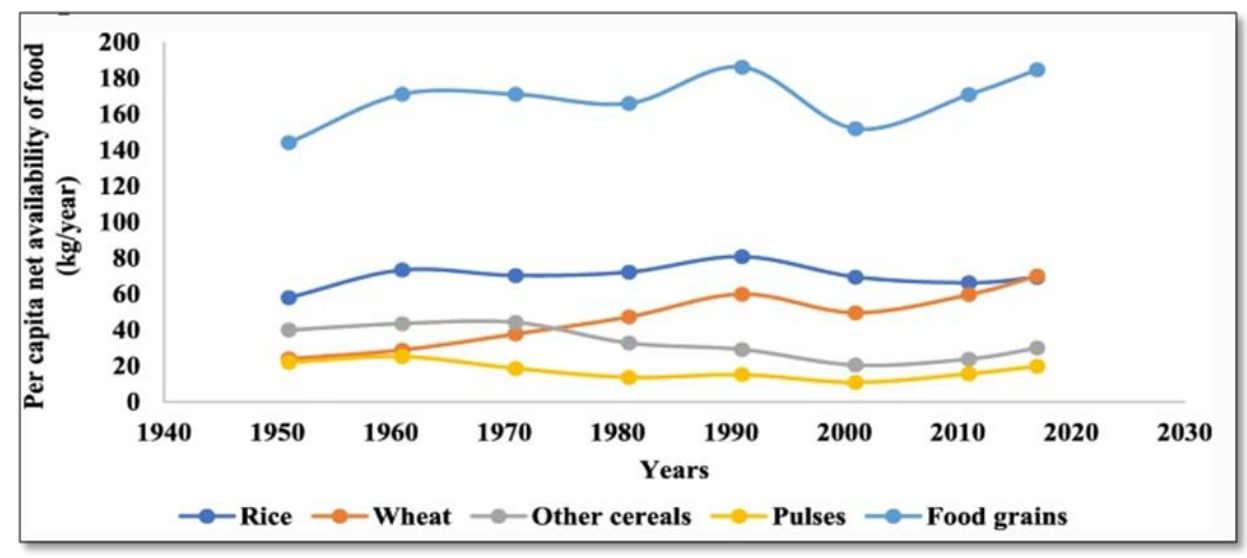


Fig.2 The nutrient content in the refined wheat and enriched wheat as compared to whole wheat flour

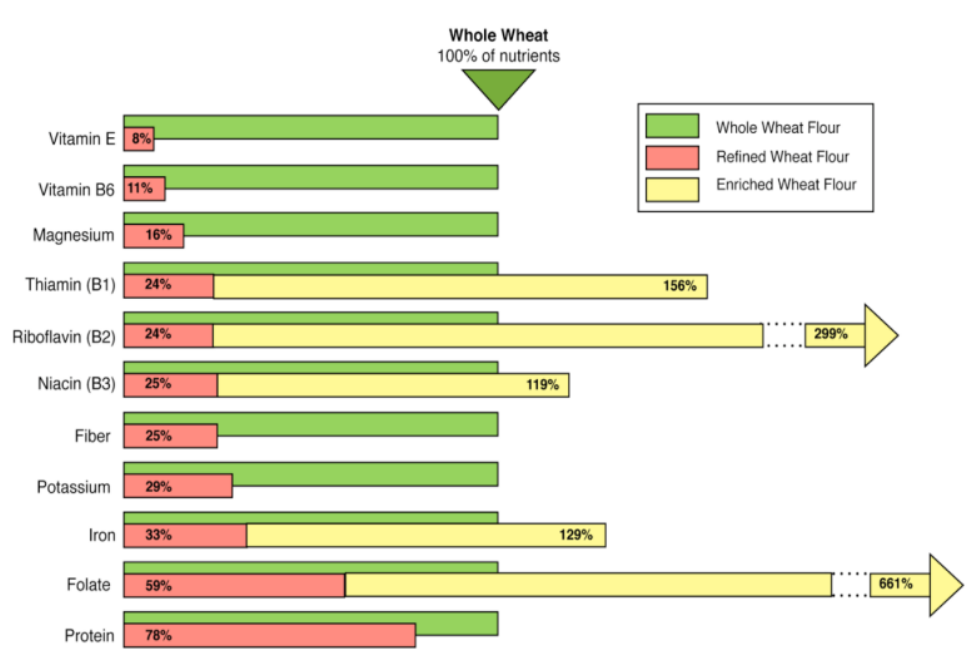

Annexure.1 Low Calorie Vegetables and Fruits (20 Kcal)

\begin{tabular}{|l|l|}
\hline Name of vegetable & \multicolumn{2}{|l|}{ Kcal/100gm } \\
\hline GLV & \multicolumn{1}{|l|}{} \\
\hline Amaranth (stem) & 19 \\
\hline Ambat chukka & 15 \\
\hline Celery stalk & 18 \\
\hline Spinach stalk & 20 \\
\hline Roots and tubers & \\
\hline Radish table & 16 \\
\hline Radish white & 17 \\
\hline Other vegetables & \\
\hline Ash gourd & 10 \\
\hline Bottle gourd & 12 \\
\hline Cluster beans & 16 \\
\hline Colocasia stem & 18 \\
\hline Cucumber & 13 \\
\hline Ghosala & 18 \\
\hline Kovai & 18 \\
\hline Parwal & 20 \\
\hline Ridge guard & 17 \\
\hline Snake guard & 18 \\
\hline Vegetable marrow & 17 \\
\hline Fruits & \\
\hline Bilimbi & 19 \\
\hline Jamb safed & 19 \\
\hline Musk melon & 17 \\
\hline Watermelon & 16 \\
\hline Orange juice & 9 \\
\hline Tomato ripe & 20 \\
\hline & \\
\hline
\end{tabular}

Source: Nutritive Value of Indian Foods, $1989^{26}$ 
For instance, leafy vegetables offer calcium and therefore supplement the comparatively small quantities of this mineral available in entire grains. Thus, the use of whole cereals as a replacement for refined cereals in Indian diet programs will provide not merely better carbohydrate options, but additionally a multitude of other micronutrient benefits. Replacing refined carbohydrates with healthier whole cereals will subtly shift regular macronutrient structure somewhat towards protein and away from carbohydrates. Besides, it's essential to prepare individuals that along with grains, fruits, and vegetables should be added considerably to the percentage of total daily calorie intake that otherwise originates only from carbohydrates.

\section{Role of Ayurveda and individual}

Emotional health is vital for a happy individual. Stimulation of a persons' mind helps in reducing anxiety and indirectly improves some other body activities. As per Ayurveda, good food choice coupled with diet routine helps to keep holistic health and wellbeing. Ayurveda, a conventional medicine system, is indigenous to India. It illustrates how exactly a person can recuperate after illness, by stating the relationships between various components of life, body and food. Based on ayurvedic ideas, food is responsible for multiple facets of a human being, including its mental, temperamental and physical states.

To remain healthy, uptake of a nutritious staple diet regularly is essential. Nutrition is the outcome of food breakdown, which is then absorbed by the body. Ayurveda states that the meal first changes into rasa (plasma), after which it successively changes into blood, reproductive elements, bone marrow, fat, muscle and body fluids. Imbalance of mind, entire body, and spirit are called diseases. Ayurveda has various healing therapies for various illnesses, and they have been constant over time. These are Shodhana, Pathyavyavastha, Rasayana, Shamana, NidanParivarjan and Satvajaya. ${ }^{34,35}$

Shodhana therapy: It is a kind of purification treatment, where poisonous elements are removed from food by the use of different operations such as peeling, washing, dehusking, straining, sifting, cleaning, cleaning, sorting, polishing, and distillation etc. Based on this therapy, the operations are specified for various food items, with nomenclature. Sifting and cleansing of cumin as well as mustard seeds are widely known as Virecana. This treatment not just eliminates the impurities but additionally enhances the health value of the food. NidanParivarjan treatment primarily considers staying away from noted causative agents of an ailment.

Rasayana therapy: It is an immune modulator as well as rejuvenation medicinebased treatment. This treatment seeks to enhance body immunity against various illnesses. All rasayanas, generally speaking, are nutrition promoters which act through three main mechanisms, viz., Rasa enhancers, Srotas and Agni enhancers. Rasa enhancers have immediate nutrient consequences; Agni enhancers stimulate the digestion power, while Srotas promote nutrient circulation.

Pathyavyavastha treatment: It generally emphasizes on dietary habits, activity and physical condition of the brain and body. Ayurveda considers meals as the foremost and first tripod (food, sleep, brahmacharya) of living. Thus, a good diet plan is crucial for health that promotes healthy body functions. Pathyavyavastha generally gives knowledge about food in the state of disease. It's completed with the perspective of improving the healing effect of diet plan, which induces the digestion energy, and also aids in assimilation and digestion of food. 
Human individual preferences are notoriously fickle, particularly when mirrored in business segments. Households decline the seed in years that are bad to vermin and rot. This particular portion has practically indeed decreased as much more systematic compilation has put into inventories. Plant explorers generally handle huge territories reducing compilation occasions by collecting in market segments along with different main places as schools. In truth, exterior initiatives to value, the marketplace, and also defend traditional knowledge, show up inevitably to distort it along with its city context.

The fundamental truth regular recognition is the town, empirical, in addition to alternative hints that indigenous individuals do not have to be worried about consistency over wide places, as geneticists, and plant collectors, should. A substantial obstacle to valuation, along with protection, could be the disarticulation of various forms of frequent knowledge. A common understanding is rife with might link substantive and managing domains and needs intense analysis to see. Variety name lists can't be worn straight framework over the farm length. The catastrophe of the Commons as well as North/South dialogue as bases for getting mechanisms to shield traditional agriculture and knowledge resources. To be insufficient to conference preservation budgets which are inadequate. Instead, gain sharing should come from much more growth assistance based on programs to improve countryside incomes in genetically different farming systems. Bilateral and multilateral advancement help that money outlying development pursuits and benefits be justified in the reciprocal duties of creating nations to developing nations. Farmers' Rights are going to vary from Breeders' Rights in they would be becoming vested in the' International Community' instead of with people. ${ }^{36,37}$
Nevertheless, by not indicating what hereditary substances are actually discussed or maybe that might Farmers' Rights have stayed an elusive goal. The qualities of the rights conferred by Farmers' Rights is dependent upon the monetary advantage sold on earlier occasions. Still, rarely an estimation of worth or maybe popular technique to compute the benefits of crop genetic resources. Likewise, estimating the price of Farmers' Rights is hampered by the absence of a method for the manner the stream of advantages to growers can be used to attain performance goals.

Bioprospecting contracts most likely provide a mechanism to offer equity and increase conservation by raising the importance of useful web online resources. Finally, the thought does not indicate whether family members that are crazy of plant life, with furnished attributes that are crucial that you crop improvement but aren't known continuously or perhaps used by farmers, are assessed by Farmers' Rights. This certification doesn't indicate a monetary incentive. They need to do benefit-sharing employing centralized financing mechanized to Breeders' Rights. These qualities lend themselves to looser as well as explicit rules about utilizing along with the influence of collective information. However, work is confounded by it to market collective action through bonuses to specific groups of farmers.

In conclusion to appropriately address the specific issues facing Asian Indians within the realm of chronic disease, clinicians must offer their patients practical approaches to incorporate in their lives. It is crucial to keep in mind, however, that Asian Indian diets are incredibly varied, and Asian Indian immigrants to the U.S. may tend to eat a blend of traditional and Western foods. Clinicians and their Asian Indian patients should work together to decide upon an 
individualized, culturally appropriate, healthy, proportionally balanced, and appetizing meal plan made with whole grains that can prevent and reduce chronic illnesses. These methods to incorporate traditional, ancient grains directly into a brand new diet plan could, additionally, be extrapolated to several different high-risk populations which may make use of culturally sensitive medical guidance on diet modification. Finally, to enact attempts against a condition which is persistent over a significant scale, governments have to alter the reasons why their policies shape consumer choices.

\section{References}

1. Avari B. 2016. India: The Ancient Past: a History of the Indian Subcontinent from C. 7000 BCE to CE 1200. Routledge, Taylor and Francis Group, London and New York.

2. Dixit AA, Azar K, Gardner CD and Palanippan L. 2011. Incorporation of whole, ancient grains into a modern Asian Indian diet to reduce the burden of chronic disease. Nutrition Reviews, 69(8): 479-88

3. Nelson ARLE, Ravichandran $\mathrm{K}$ and Antony U. 2019. The impact of the Green Revolution on indigenous crops of India. Journal of Ethnic Foods, 6(8)

4. Fieldhouse P. 2013. Food and nutrition: customs and culture. Springer

5. Shanahan C. 2017. Deep nutrition: Why your genes need traditional food Macmillan, New York.

6. Mohan V, Radhika G, Sathya RM, Tamil SR, Ganesan A, Sudha V. 2009. Dietary carbohydrates, glycemic load, food groups and newly detected type 2 diabetes among urban Asian Indian population in Chennai, India (Chennai Urban Rural Epidemiology Study 59). Br J Nutr102:1498-1506.

7. Christian IA, Augustine $\mathrm{CO}$ and
Chijioke MO. 2015. Functional components and medicinal properties of food: a review. Journal of Food Science and Technology 52: 2522-2529.

8. Atanu Sarkar, Kristan J. A, Shantagouda Patil Lingappa, B. Hugar, Gary W. vanLoon 2012 Emerging health risks associated with modern agriculture practices: A comprehensive study in India. Environmental Research115: 3750.

9. Devi GN, Padmavathi G, Babu VR, Waghray K. Proximate nutritional evaluation of Rice (Oryza sativa L.). J Rice Res. 2015;8(1):23-32.

10. Longvah T, Ananthan R, Bhaskarachary $\mathrm{K}$, Venkaiah K. Proximate principles and dietary fibre. In: Indian Food Composition Tables, National Institute of Nutrition, Department of Health Research, Ministry of Health and Family Welfare, Government of India, Hyderabad. 2017.

11. Saikia S, Dutta H, Saikia D, Mahanta CL. Quality characterization and estimation of phytochemicals content and antioxidant capacity of aromatic pigmented and non-pigmented rice varieties. Food Res Int. 2012; 46(1): 334-40.

12. Sompong $R$, Siebenhandl-Ehn $S$, Linsberger-Martin G, Berghofer E. Physicochemical and antioxidative properties of red and black rice varieties from Thailand, China and Sri Lanka. Food Chem. 2011; 124: 132-40.

13. Trichopoulou A, Martinez-Gonzalez AA, Tong TYN, Forouhi NG, Khandelwal S, Prabhakaran D, Mozaffarian D and LorgerilMde. 2014. Definitions and potential health benefits of the Mediterranean diet: views from experts around the world. $B M C$ Medicine, 12:112. https://doi.org/10.1186/1741-7015-12112 
14. Gopalan C, Rama Sastri BV, Balasubramanian SC, Naerasinga Rao BS, Deosthale YG, Pant KC. 2009. Nutritive Value of Indian Foods. National Institute of Nutrition, Hyderabad, India.

15. Das A, Raychaudhuri $U$ and Chakraborty R. 2012. Cereal based functional food of Indian subcontinent: a review. Journal of Food Science and Technology 49: 665-672.

16. Eliazer Nelson, A.R.L., Ravichandran, K. \& Antony, U. The impact of the Green Revolution on indigenous crops of India. J. Ethn. Food6, 8 (2019). https://doi.org/10.1186/s42779-0190011-9

17. Directorate of Economics and Statistics (DES), Ministry of Agriculture, India. 2014. https://eands.dacnet.nic.in/PDF/ Glance-2016.pdf.

18. Department of Agriculture, Cooperation and Farmers Welfare, India. 2017. http://agricoop.nic.in/sites/default/files/p ocketbook_0.pdf

19. Dubey KG. 2010. The Indian cuisine. PHI Learning, Delhi.

20. National Research Council. Diet and Health : Implications for Reducing Chronic Disease Risk. National Academy Press, Washington DC, 1989.

21. Slavin JL, Jacobs D, Marquart L, Wiemer K. 2001 The role of whole grains in disease prevention. J Am Diet Assoc 101:780-785.

22. Montonen J, Knekt $\mathrm{P}$, Jarvinen $\mathrm{R}$, Aromaa A, Reunanen A. 2003. Wholegrain and fiber intake and the incidence of type 2 diabetes. Am J Clin Nutr77:622-629.

23. Chandalia M, Garg A, Lutjohann D, von Bergmann K,Grundy SM, Brinkley LJ. 2000 Beneficial effects of high dietary fiber intake in patients with type 2 Diabetes mellitus. $N$ Engl $J$ Med 342:1392-1398.
24. de Munter JS, Hu FB, Spiegelman D, Franz M, van Dam RM. 2007. Whole grain, bran, and germ intake and risk of type 2 diabetes: a prospective cohort study and systematic review. PLoS Med4:e261.

25. Montonen J, Knekt $\mathrm{P}$, Jarvinen R, Aromaa A, Reunanen A. 2003. Wholegrain and fiber intake and the incidence of type 2 diabetes. Am $J$ Clin Nutr77:622-629.

26. Venn BJ, Mann JI. Cereal grains, legumes and diabetes. 2004. Eur J Clin Nutr58:1443-1461.

27. Flight I and Clifton P. 2006 Cereal grains and legumes in the prevention of coronary heart disease and stroke: a review of the literature. Eur J Clin Nutr60:1145-1159.

28. Jimenez-Cruz A, Bacardi-Gascon $\mathrm{M}$, Turnbull WH, Rosales-Garay P, Severino-Lugo I. 2003. A flexible, lowglycemic index Mexican-style diet in overweight and obese subjects with type 2 diabetes improves metabolic parameters during a 6-week treatment period. Diabetes Care26:1967-1970.

29. Abete I, Astrup A, Martinez JA, Thorsdottir I, Zulet MA. 2010. Obesity and the metabolic syndrome: role of different dietary macronutrient distribution patterns and specific nutritional components on weight loss and maintenance. Nutr Rev68:214-231.

30. Maki KC, Rains TM, Kaden VN, Raneri KR, Davidson MH. 2007. Effects of a reduced-glycemic-load diet on body weight, body composition, and cardiovascular disease risk markers in overweight and obese adults. Am J Clin Nutr85:724-734.

31. Astrup A. 2005. The satiating power of protein-a key to obesity prevention? Am J ClinNutr82:1-2.

32. Shobana S, Kumari SR, Malleshi NG, Ali SZ. 2007. Glycemic response of rice, 
wheat and finger millet based diabetic food formulations in normoglycemic subjects. Int J Food Sci Nutr, 58:363372.

33. Nishizawa N, Togawa T, Park KO, et al. 2009 Dietary Japanese millet protein ameliorates plasma levels of adiponectin, glucose, and lipids in type 2 diabetic mice. BiosciBiotechnolBiochem 73: 351-360.

34. Liebler N, Moss S. Healing depression the mind-body way: Creating happiness with meditation, yoga, and ayurveda. John Wiley \& Sons; 2009.
35. Chauhan SK, Sharma R, Chander J. Short rotation forestry: it's application for biomass, energy, soil health and carbon sequestration. Agroforestry strategies for climate change: mitigation and adaptation Jaya Publishing House, Delhi. 2017; 139-168.

36. Amato JA. Dust: A History of the Small and the Invisible. Univ of California Press; 2001.

37. Lindemann M. Medicine and society in early modern Europe. Cambridge University Press; 2010.

\section{How to cite this article:}

Isha Sharma, Inderpreet Kaur Dhaliwal, Priyanka Bijalwan, Vinod Kumar Yadav and Prashant Kaushik. 2020. A Brief Perspective on Lost Traditional Grains and Food Habits of Indians. Int.J.Curr.Microbiol.App.Sci. 9(12): 2295-2305. doi: https://doi.org/10.20546/ijcmas.2020.912.272 